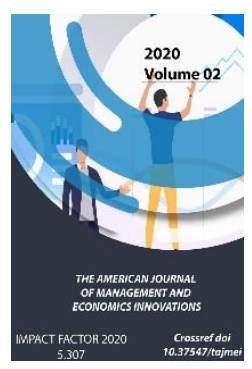

\title{
Multi-Factor Modeling And Forecasting Of Employment Indicators In The National Labor Market Of Uzbekistan
}

\author{
Asrakulov Abdurakhmon Sultonovich \\ Doctoral Student, Ferghana State University, Ferghana City, Uzbekistan
}

Copyright: Original

content from this work

may be used under the

terms of the creative

commons attributes

4.0 licence.

\section{ABSTRACT}

In the research theoretically studied and classified the characteristics of the factors for the multi-factor analysis of the employment indicators of the population. On the basis of theoretical research, analyzed employment indicators in the labor market of the Republic of Uzbekistan on the basis of the multifactor link and determined econometric model. On the identified regression models, developed forecast indicators of the main employment indicators for 2020-2026 years and directions for effective employment in the labor market.

\section{KEYWORDS}

Labor market, employment, factors affecting employment, exogen and endogen factors, correlationregression analysis, autocorrelation, non-linear correlation, regression model.

\section{INTRODUCTION}

At the present stage of the globalization process, the role of indicators reflecting the socio-economic development of different countries not only in the expression of economic indicators, but also in the assessment of the level of social development of the country is increasing.

If we take into account that the main part of social indicators consists of indicators related to employment and employment of the population, as well as the emphasis on "human 
capital" as the main factor of economic growth in developed countries today, the importance of employment and social relations associated with it, will be more pronounced.

With the development of socio-economic relations at the present stage of the development of the world economy, the employment situation and its forms are significantly different from the traditional approaches to employment.

According to the World Bank, the number of the world's population in 2019 amounted to 7,6 billion, 5,7 billion of them (75,0 \%) labor resources, and 3.3 billion (57,9\%) labor resources are employed, 2,2 billion of them are unemployed and ready-to-work labor resources. The analysis of the employed world population in these reports on individual criteria indicates that, $61 \%$ of the employed population is informal employed, $52 \%$ are paid employers, $26 \%$ of the employed population is an extreme and average poor part of the population $[1,5]$.

In particular, a large part of the employed population in different countries of the world lost their permanent jobs (for example, in the US in 2020 year in the last two weeks of March 10 million people) as a result of the coronavirus (COVID-19 virus) pandemic, which began in December 2019 year and today covers almost all countries of the world [2].

Taking into account the above-mentioned changes and features, there is an increasing need for scientific research that provides for the research and analysis of the world labor market situation, the regulation and management of employment processes taking into account the influence of factors on employment, the supply of qualified labor resources for economic sectors and sectors, as well as the quantitative and qualitative. Due to these needs, special attention paid to scientific research in the direction of assessing the impact of employment and factors on it in most countries of the world, researching the employment situation in the labor market, improving the performance of effective employment.

\section{MATERIALS AND METHODS}

It is important to conduct an econometric analysis of socio-economic indicators and determine the main group of factors on the process under study at the initial stage of modeling. This increases the objectivity of the analysis by placing factors on the econometric model with the correct determination of the endogen factor in the process and the degree of correlation with the affecting factors and their resulting factor.

In the classification of economic resources by B.M.Genkin, the process of aggregation of labor capacity in the production process with natural resources and production resources is very clearly described. In the result of this research, it is emphasized that in the production process, natural resources in the form of raw materials, materials and other resources, as well as the creation of products or services as a result of their combination with capital, buildings, structures, machine-building production lines and other seemingly productive resources, will be used [3, 88-89].

Factors affecting employment of labor resources in the economy have been studied by various researchers and in general factors, affecting employment are divided into 2 groups - external and internal factors [4, 89101].

As external factors affecting the employment of labor resources, can be considered political, economic, technological and social factors (Tab.1). 
Table 1

Classification of external factors affecting employment [5, 2331]

\begin{tabular}{|c|c|c|}
\hline $\begin{array}{l}\text { Groups of } \\
\text { factors }\end{array}$ & Types of factors & Impact content \\
\hline \multirow{3}{*}{$\begin{array}{l}\text { Political } \\
\text { factors }\end{array}$} & $\begin{array}{l}\text { Stability of the } \\
\text { political situation in } \\
\text { the country }\end{array}$ & $\begin{array}{l}\text { This factor has a direct affect to the increasing or } \\
\text { decreasing of the level of employment of labor } \\
\text { resources. }\end{array}$ \\
\hline & $\begin{array}{l}\text { The efficiency of the } \\
\text { legislative system in } \\
\text { the country }\end{array}$ & $\begin{array}{l}\text { The efficiency of the legislative system in the } \\
\text { country determines the degree of informality or } \\
\text { legality of the employment situation, that is, it } \\
\text { affects the distribution of employment in a informal } \\
\text { or legalized economy. }\end{array}$ \\
\hline & $\begin{array}{l}\text { The quality of state } \\
\text { regulation of socio- } \\
\text { economic processes }\end{array}$ & $\begin{array}{l}\text { The qualitative characteristics of the state } \\
\text { regulation of taxation, budget, investments, prices } \\
\text { and other processes have their impact to the } \\
\text { employment. }\end{array}$ \\
\hline \multirow{3}{*}{$\begin{array}{l}\text { Economic } \\
\text { factors }\end{array}$} & $\begin{array}{c}\text { Efficiency of market } \\
\text { mechanism }\end{array}$ & $\begin{array}{l}\text { The efficiency level of market mechanism is in the } \\
\text { right correlation with the employment rate, and if } \\
\text { the efficiency is high, the employment rate } \\
\text { increases, if low, the employment situation } \\
\text { worsens. }\end{array}$ \\
\hline & $\begin{array}{c}\text { Stability of the tax } \\
\text { system }\end{array}$ & $\begin{array}{l}\text { The stability of the tax system provides a stable } \\
\text { employment with the stability of the level of } \\
\text { economic activity on the territory of the country. }\end{array}$ \\
\hline & $\begin{array}{l}\text { Stability of financial } \\
\text { and credit system }\end{array}$ & $\begin{array}{l}\text { The immutability of the long-term strategy of the } \\
\text { financial and credit system leads to the optimal level } \\
\text { of employment situation by ensuring the stability of } \\
\text { the level of economic activity in the coming period. }\end{array}$ \\
\hline
\end{tabular}




\begin{tabular}{|c|c|c|}
\hline \multirow{5}{*}{$\begin{array}{l}\text { Technological } \\
\text { factors }\end{array}$} & $\begin{array}{l}\text { The level of } \\
\text { innovation activity } \\
\text { in the country }\end{array}$ & $\begin{array}{l}\text { The level of innovation activity will affect the } \\
\text { change in the employment rate according to new } \\
\text { forms of employment with the introduction of } \\
\text { innovations. }\end{array}$ \\
\hline & $\begin{array}{l}\text { Level of application } \\
\text { of modern IT }\end{array}$ & $\begin{array}{l}\text { With the introduction of additional requirements } \\
\text { for the qualification of labor resources, there is an } \\
\text { impact on the change in the level of employment. }\end{array}$ \\
\hline & $\begin{array}{l}\text { Progressivity of } \\
\text { technological } \\
\text { processes }\end{array}$ & $\begin{array}{l}\text { The addition of additional knowledge and } \\
\text { qualification requirements, as well as the reduction } \\
\text { of handicraft work, affects the change in the } \\
\text { employment rate. }\end{array}$ \\
\hline & $\begin{array}{l}\text { Mobility of } \\
\text { technology }\end{array}$ & $\begin{array}{l}\text { Easyness of moving technology from one place to } \\
\text { another makes it possible to create new jobs in } \\
\text { different regions. }\end{array}$ \\
\hline & $\begin{array}{l}\text { Professionalism of } \\
\text { employees }\end{array}$ & $\begin{array}{l}\text { Changes in the requirements for the qualification } \\
\text { level of labor resources in the labor market lead to } \\
\text { the formation of a system of training of qualified } \\
\text { workers. }\end{array}$ \\
\hline \multirow[b]{2}{*}{ Social factors } & $\begin{array}{l}\text { The level and quality } \\
\text { of welfare of the } \\
\text { population }\end{array}$ & $\begin{array}{l}\text { Changes in the level of income have an impact on } \\
\text { the change in the level and quality of welfare. }\end{array}$ \\
\hline & $\begin{array}{l}\text { The level and quality } \\
\text { of education of the } \\
\text { population }\end{array}$ & $\begin{array}{l}\text { New jobs that require modern knowledge } \\
\text { determine the requirements for the quality of the } \\
\text { busy people, as they require different new } \\
\text { knowledge for new industries. }\end{array}$ \\
\hline
\end{tabular}

Political factors include the effects arising from the circumstances associated with the stability of the political situation in the country, the effectiveness of the existing legislative system, as well as the state regulation of various socio- economic processes, which are important factors in the state of employment of labor resources among the remaining factors of the external group of factors. 
Economic factors include the effectiveness of the market forces acting in the country's economy, the effects of taxation and the stability of financial and credit systems. The impact of these factors can be seen in the creation of new jobs through preferential taxation and lending, direct financing of business, support for employment forms.

Among the technological factors, can be included the level of activity of the population in the introduction of innovations, the application of modern information technologies in socio-economic processes, the progress of the current technological processes, the mobility of these technologies, the level of qualification of employees in the application of technologies and other factors.

Social factors are also considered as the basis of a group of external factors, affecting the employment of labor resources through the level and quality of welfare of the population, the level and quality of education, as well as cultural values.

The impact of social factors on employment is observed with the emergence of personal characteristics (mobility, motivation, aspiration for innovation, aspiration to improve professional skills, effort to meet the qualification requirements), which are formed as a result of the achievement of a high standard of living of labor resources. According to experts, these qualities are one of the main factors in increasing labor productivity, as well as in increasing the income of labor resources $[6,222]$.

The trends of positive changes in the employment level largely depend on the joint impact of the external factors considered above, but in most cases the possibility of managing them remains limited. Because it depends not only on the business environment in the economy, but also on the state management structures. In such cases, the effective impact of factor management should be relied on internal factors which consist of relationship between government structures and employers [7].

On the basis of theoretically classified external and internal factors management, taking into account the socio-economic situation in the country, the level of economic development as well as national characteristics, the following 5 models of employment and labor market regulation have been formed and are being used in practice today:

1. The US model of employment and labor market regulation. The basis of this model is the subsidization of social Labor Relations, the purpose of which is to ensure the full manifestation of their abilities on the basis of ensuring the personal success of the employee [8, 261].

2. The "Swedish" model of employment and labor market regulation. This model relies on the following three basic principles in the labor market and employment regulation:

a. To achieve full employment of the labourable population;

b. Providing social guarantees to the population;

c. To give equal opportunities to the population in achieving the well-being of welfare [9, 13-16].

3. Anglosakson (UK, Canada, Ireland) model of employment and labor market regulation. This model differs from other models in that the public employment policy is relatively sluggish, the main activity in the provision of Social Services is provided by private and public organizations [10, 109-115].

4. The "continental" or "German" model of employment and labor market regulation (Germany, Austria, Belgium, the Netherlands, Sweden and partly France). For this model, as in the "Swedish" model, the movement is characteristic of ensuring a high level of employment and a partial decrease in the level of employment in the case of increased labor productivity. The 


\begin{abstract}
"German" or "neoliberal" employment model is based on an active employment policy, that is, the state, together with the support of all enterprises creating new jobs, allocates benefits and subsidies to modernized enterprises in order to prevent the dismissal of workers to the frontline [11, 50-54].

5. The "Japanese" model of employment and labor market regulation. This model is based on a lifetime guarantee of workers and an increase in the amount of wages in proportion to their work experience. As a result of the "Japanese" model, it can be shown that the unemployment rate in Japan in recent years is 3-3, 5 \% (natural unemployment rate). According to many researchers, this model differs from other models by its national characteristics and its scanning can not be supported in other countries [10, 109-115].
\end{abstract}

\section{RESULT AND DISCUSSION}

The situation and level of employment in the labor market is characterized by the level of various factors that affect its formation. The above was studied on the scale and characteristics of the impact of factors affecting the level of employment of the population and its effectiveness, and the classification of factors was determined. Using

Table 2 this classification, it is aimed to study the impact of various factors on the level of employment in our country, relying on accurate statistical data, as well as to develop proposals on the areas of factors management in ensuring effective employment in the national labor market in the future, based on the level of factors influence $[12,13,14,15]$.

In the theoretical part of the study, attempted to determine the effect of effective employment of the population used PEST (political, economic, socio-demographic, technological factors) analysis, which affects the level of employment of the population in today's environment.

PEST analysis is an analysis based on the assessment of the impact load on the process of individual factors obtained in the composition of these factor groups on the basis of political, economic, socio-demographic and technological factors determination affecting the process under study $[16,17,18$, 19].

To carry out the PEST analysis, initially, the factors affecting the effective employment of the population in the labor market were identified by 4 groups and grouped into separate groups were included in the table (Tab. 2).

Factors affecting the employment of the population obtained for PEST analysis and their level of influence ${ }^{1}$

\begin{tabular}{|c|c|c|c|}
\hline Factor Group and type & $\begin{array}{c}\text { The degree } \\
\text { of influence } \\
\text { of the } \\
\text { factor* }\end{array}$ & Factor Group and type & $\begin{array}{c}\text { The degree of } \\
\text { influence of } \\
\text { the factor* }\end{array}$ \\
\hline \multicolumn{2}{|c|}{ Group of Political factors } & Average nominal salary amount & 3 \\
\hline Political stability of the state & 2 & \multicolumn{2}{|c|}{ Group of Economic factors } \\
\hline
\end{tabular}

\footnotetext{
${ }^{1}$ Done by author.
} 
The American Journal of Management and Economics Innovations

(ISSN - 2693-0811)

Published: December 31, 2020 | Pages: 27-47

Doi: https://doi.org/10.37547/tajmei/Volume02Issue12-06

\begin{tabular}{|c|c|c|c|}
\hline $\begin{array}{l}\text { The degree of bureaucracy and } \\
\text { corruption }\end{array}$ & 1 & $\begin{array}{c}\text { Consumer Price Index (inflation } \\
\text { rate) }\end{array}$ & 3 \\
\hline Tax policy & 3 & Unemployment rate & 2 \\
\hline $\begin{array}{c}\text { Changes in the state regulation of } \\
\text { the labor market }\end{array}$ & 2 & $\begin{array}{l}\text { The share of small business and } \\
\text { private entrepreneurship at the level } \\
\text { of employment }\end{array}$ & 3 \\
\hline $\begin{array}{l}\text { The level of validity of labor } \\
\text { legislation }\end{array}$ & 2 & Number of operating enterprises & 3 \\
\hline \multicolumn{2}{|c|}{ Group of socio-demographic factors } & $\begin{array}{l}\text { Investment volume of the main } \\
\text { capital per capita }\end{array}$ & 3 \\
\hline Education and health level & 1 & Interest rate & 2 \\
\hline $\begin{array}{c}\text { Number of population in working } \\
\text { age }\end{array}$ & 3 & \multicolumn{2}{|c|}{ Group of technological factors } \\
\hline $\begin{array}{c}\text { Number of new jobs created in } \\
\text { economic sectors }\end{array}$ & 2 & Level of using of innovation & 2 \\
\hline Migration balance & 3 & Expenditures for scientific research & 2 \\
\hline Life expectancy of population & 1 & $\begin{array}{l}\text { The opportunity to buy new } \\
\text { technologies }\end{array}$ & 1 \\
\hline Families size and composition & 1 & $\begin{array}{l}\text { The level of implementation of new } \\
\text { technologies }\end{array}$ & 3 \\
\hline
\end{tabular}

* Due to the method of PEST analysis, the degree of impact of the factor determined in the range of 1-3.

Used the results of the leading experts of the regional departments of the Ministry of economic development and poverty reduction, also Employment and Labor Relations of the Republic of Uzbekistan in order to assess the level of influence of the factor in the composition of each factor group on the employment of the population, as well as the significance of this factor.

Among the political factors were selected such factors as political stability of the state, the degree of bureaucracy and corruption, tax policy, changes in the state regulation of the sphere, the level of validity of labor legislation.

As economic factors selected factors such as economic (GDP) growth rate, Consumer Price Index (inflation rate), core capital per capita investment, number of operating enterprises, share of small business and private entrepreneurship at the level of employment, unemployment rate, average nominal wage rate, interest rate.

Socio-demographic factors affecting employment are factors such as the level of education and health, population growth in 
working age, number of new jobs created in economic sectors, migration balance, life expectancy of the population, size and composition of families [20, 21, 22, 23, 24].

As technological factors affecting employment selected factors such as the level of use of innovation, the expenditure for scientific research and work, the possibility of acquiring new technologies, the level of introduction of new technologies $[25,26,27]$.

The level of influence of the factors combined into 4 groups by experts determined on the basis of the range from 1-3, depending on the method of PEST analysis. The degree of impact force of factors expresses the following characteristics of each level:

1 - the level of influence of the factor is low, any change of the factor practically does not affect the level of employment in the labor market.

2 - a significant change in the factor indicates its impact on the employment level in the labor market.

3 - the level of influence of the factor is high, any fluctuations in the factor indicator indicate its impact on the level of employment in the labor market.
The impact strength of the factors determined on the level of influence assessed by experts and the results of the analysis on the level of influence and impact strength of the factors affecting employment in the labor market summarized in Table 3.

When studied the overall level of factors impact and the impact force, based on the conclusion of the experts, determined the level of impact on the change in the number of employed population in the labor market and the factors with the highest impact force belong to the group of socio-demographic and economic factors.

Both in the group of political factors and technological factors, there are factors that have a high level of influence and strength (tax policy, the level of introduction of new technologies, changes in the state regulation of the labor market, etc.), however, due to the absence of statistical indicators that reflect the quantitative aspects of these factors, the level of influence and the strength of influence as factors affecting the change in the number of employed population (resultant factor) selected from the following factors belonging to the group of economic and sociodemographic factors, which considered high by experts:

Table 3

The price of the real importance of PEST-factors ${ }^{2}$

\begin{tabular}{|c|c|c|c|c|c|c|c|c|}
\hline \multirow[b]{2}{*}{ Factor Group and type } & \multirow{2}{*}{$\begin{array}{c}\text { The } \\
\text { degree of } \\
\text { influence } \\
\text { of the } \\
\text { factor * }\end{array}$} & \multicolumn{5}{|c|}{ Expert assessment } & \multirow[b]{2}{*}{$\begin{array}{c}\text { Average } \\
\text { rating }\end{array}$} & \multirow{2}{*}{$\begin{array}{c}\text { The } \\
\text { impact } \\
\text { force of } \\
\text { the } \\
\text { factor }\end{array}$} \\
\hline & & 1 & 2 & 3 & 4 & 5 & & \\
\hline
\end{tabular}

${ }^{2}$ Developed by the author based on the conclusions. 
The American Journal of Management and Economics Innovations

Doi: https://doi.org/10.37547/tajmei/Volume02Issue12-06

\begin{tabular}{|c|c|c|c|c|c|c|c|c|}
\hline Average nominal salary amount & 3 & 4 & 4 & 5 & 4 & 3 & 4,0 & 0,42 \\
\hline $\begin{array}{l}\text { Consumer Price Index (inflation } \\
\text { rate) }\end{array}$ & 3 & 5 & 5 & 4 & 4 & 3 & 4,2 & 0,45 \\
\hline Unemployment rate & 2 & 3 & 3 & 4 & 3 & 3 & 3,2 & 0,27 \\
\hline $\begin{array}{l}\text { The share of small business and } \\
\text { private entrepreneurship at the } \\
\text { level of employment }\end{array}$ & 3 & 4 & 4 & 5 & 3 & 3 & 3,8 & 0,41 \\
\hline $\begin{array}{l}\text { Number of operating } \\
\text { enterprises }\end{array}$ & 3 & 4 & 5 & 5 & 5 & 3 & 4,4 & 0,47 \\
\hline $\begin{array}{l}\text { Investment volume of the main } \\
\text { capital per capita }\end{array}$ & 3 & 4 & 5 & 5 & 5 & 4 & 4,6 & 0,51 \\
\hline Interest rate & 2 & 3 & 4 & 2 & 3 & 3 & 3,0 & 0,19 \\
\hline \multicolumn{9}{|c|}{ Group of socio-demographic factors } \\
\hline Education and health level & 1 & 3 & 4 & 2 & 2 & 3 & 2,8 & 0,08 \\
\hline $\begin{array}{l}\text { Number of population in } \\
\text { working age }\end{array}$ & 3 & 4 & 4 & 5 & 5 & 5 & 4,6 & 0,48 \\
\hline $\begin{array}{l}\text { Number of new jobs created in } \\
\text { economic sectors }\end{array}$ & 2 & 4 & 3 & 4 & 4 & 3 & 3,6 & 0,34 \\
\hline Migration balance & 3 & 4 & 4 & 5 & 5 & 4 & 4,4 & 0,44 \\
\hline Life expectancy of population & 1 & 2 & 2 & 4 & 1 & 3 & 2,4 & 0,11 \\
\hline Families size and composition & 1 & 2 & 1 & 2 & 2 & 3 & 2,0 & 0,12 \\
\hline \multicolumn{9}{|c|}{ Group of technological factors } \\
\hline Level of using of innovation & 2 & 3 & 3 & 5 & 4 & 3 & 3,6 & 0,18 \\
\hline $\begin{array}{l}\text { Expenditures for scientific } \\
\text { research }\end{array}$ & 2 & 4 & 2 & 3 & 3 & 3 & 3,0 & 0,13 \\
\hline $\begin{array}{l}\text { The opportunity to buy new } \\
\text { technologies }\end{array}$ & 1 & 1 & 3 & 2 & 3 & 3 & 2,4 & 0,09 \\
\hline
\end{tabular}




\begin{tabular}{|l|l|l|l|l|l|l|l|l|}
\hline $\begin{array}{l}\text { The level of implementation of } \\
\text { new technologies }\end{array}$ & 3 & 4 & 5 & 4 & 3 & 4 & 4,0 & 0,38 \\
\hline
\end{tabular}

\section{Average nominal salary amount.}

2. Investment volume of the main capital per capita.

3. Number of population in working age.

4. Number of operating enterprises.

5. Consumer Price Index (inflation rate).

6. Migration balance.

7. The share of small business and private entrepreneurship at the level of employment.
The above-mentioned impact ex-indicators and end-factor indicators reflecting the number of employed population in the economy separated from the official data of the State Statistics Office for 2010-2019 years and placed into the table.

In Table 4 presented, the number of employed population $(Y)$ in the economy determined to have a steady growth trend over the years, and the change model of this indicator has a nonlinear correlation.

Table 4

The amount of factor indicators in the Republic of Uzbekistan for 2010-2019 years 3

\begin{tabular}{|c|c|c|c|c|c|c|c|c|c|c|}
\hline \multirow{2}{*}{ Indicators } & \multicolumn{10}{|c|}{ Years } \\
\hline & 2010 & 2011 & 2012 & 2013 & 2014 & 2015 & 2016 & 2017 & 2018 & 2019 \\
\hline $\begin{array}{l}\text { Number of } \\
\text { employed } \\
\text { population in the } \\
\text { economy (Y), } \\
\text { thousand people }\end{array}$ & $\begin{array}{c}11628 \\
4\end{array}$ & 11919,1 & $\begin{array}{c}12223 \\
8\end{array}$ & $\begin{array}{c}12523 \\
3\end{array}$ & $\begin{array}{c}12818 \\
4\end{array}$ & $\begin{array}{c}13058 \\
3\end{array}$ & $\begin{array}{c}13298 \\
, 4\end{array}$ & $\begin{array}{c}13520 \\
, 3\end{array}$ & 13273 & $\begin{array}{c}13722 \\
8\end{array}$ \\
\hline $\begin{array}{l}\text { Average nominal } \\
\text { salary amount } \\
\left(X_{1}\right) \text {, thousand } \\
\text { sum }\end{array}$ & 504,8 & 628,1 & 739,7 & 865,9 & $\begin{array}{c}1007 \\
9\end{array}$ & 1171,7 & $\begin{array}{c}1293 \\
8\end{array}$ & $\begin{array}{c}1457 \\
8\end{array}$ & $\begin{array}{c}1822 \\
7\end{array}$ & $\begin{array}{c}2243 \\
9\end{array}$ \\
\hline $\begin{array}{l}\text { Investment } \\
\text { volume of the } \\
\text { main capital per }\end{array}$ & 672,4 & 709,6 & 821,3 & $\begin{array}{c}1008 \\
2\end{array}$ & $\begin{array}{c}1224 \\
0\end{array}$ & 1431,7 & $\begin{array}{c}1608 \\
6\end{array}$ & $\begin{array}{c}2227 \\
8\end{array}$ & $\begin{array}{c}3769 \\
6\end{array}$ & $\begin{array}{c}4097 \\
3\end{array}$ \\
\hline
\end{tabular}

${ }^{3}$ Developed by the author on the basis of data of the State Statistics Committee of the Republic of Uzbekistan. 


\begin{tabular}{|c|c|c|c|c|c|c|c|c|c|c|}
\hline $\begin{array}{l}\text { capita }\left(X_{2}\right) \\
\text { thousand sum }\end{array}$ & & & & & & & & & & \\
\hline $\begin{array}{l}\text { Number of } \\
\text { population in } \\
\text { working age }\left(X_{3}\right) \text {, } \\
\text { thousand people }\end{array}$ & $\begin{array}{c}16953 \\
, 6\end{array}$ & $\begin{array}{c}17804 \\
7\end{array}$ & $\begin{array}{c}18184 \\
6\end{array}$ & $\begin{array}{c}18517 \\
6\end{array}$ & $\begin{array}{c}18814 \\
, 0\end{array}$ & $\begin{array}{c}19044 \\
, 1\end{array}$ & $\begin{array}{c}19257 \\
, 0\end{array}$ & $\begin{array}{c}1944 \\
0,8\end{array}$ & $\begin{array}{c}19610 \\
, 1\end{array}$ & $\begin{array}{c}19791 \\
7\end{array}$ \\
\hline $\begin{array}{l}\text { Number of } \\
\text { operating } \\
\text { enterprises }\left(\mathrm{X}_{4}\right) \text {, } \\
\text { thousand units }\end{array}$ & 201,3 & 213,1 & 238,6 & 266,4 & 273,6 & 278,4 & 285,4 & 300,2 & 323,5 & 341,7 \\
\hline $\begin{array}{l}\text { Consumer Price } \\
\text { Index (inflation } \\
\text { rate) }\left(X_{5}\right), \%\end{array}$ & 107,3 & 107,6 & 107,0 & 106,8 & 106,1 & 105,6 & 105,7 & 114,4 & 114,3 & 115,2 \\
\hline $\begin{array}{l}\text { Migration balance } \\
\left(X_{6}\right) \text {, people }\end{array}$ & $\begin{array}{c}4408 \\
3\end{array}$ & -47584 & -40952 & $\begin{array}{c}3456 \\
6\end{array}$ & $\begin{array}{c}3856 \\
2\end{array}$ & $\begin{array}{c}- \\
29299\end{array}$ & $\begin{array}{c}2624 \\
8\end{array}$ & $\begin{array}{c}1859 \\
9\end{array}$ & 14729 & $\begin{array}{c}- \\
13892\end{array}$ \\
\hline $\begin{array}{l}\text { The share of small } \\
\text { business and } \\
\text { private } \\
\text { entrepreneurship } \\
\text { at the level of } \\
\text { employment }\left(\mathrm{X}_{7}\right) \text {, } \\
\%\end{array}$ & 74,7 & 75,1 & 75,6 & 76,7 & 77,6 & 77,9 & 78,2 & 78,0 & 76,3 & 77,3 \\
\hline
\end{tabular}

Based on the conclusions, we determine the density (correlation coefficients) of the correlation of the factors assessed as the degree of influence on the resultant factor and the strength of the impact on the resultant factor (Tab. 5).

Table 5 


\section{Correlation coefficient values of selected factors ${ }^{4}$}

\begin{tabular}{|ccccccccc|}
\hline & $Y$ & $X_{1}$ & $X_{2}$ & $X_{3}$ & $X_{4}$ & $X_{5}$ & $X_{6}$ & $X_{7}$ \\
\hline$Y$ & 1 & & & & & & & \\
$X_{1}$ & 0,910361 & 1 & & & & & & \\
$X_{2}$ & 0,733068 & 0,937283 & 1 & & & & & \\
$X_{3}$ & 0,995639 & 0,892354 & 0,71377 & 1 & & & & \\
$X_{4}$ & 0,863642 & 0,981464 & 0,65975 & 0,73971 & 1 & & & \\
$X_{5}$ & $-0,354146$ & $-0,064703$ & 0,08043 & $-0,39137$ & $-0,062260$ & 1 & & \\
$X_{6}$ & 0,906046 & 0,894689 & 0,74510 & 0,89430 & 0,824504 & $-0,055242$ & 1 & \\
$X_{7}$ & 0,97662 & 0,835013 & 0,60929 & 0,77473 & 0,761981 & $-0,382168$ & 0,90054 & 1 \\
\hline
\end{tabular}

he double correlation coefficients of the $x_{1}$ and $x_{6}$ exogen factors were excluded from the model, which were not significantly higher (forming autocorrelation) due to the value, that is, the density of the bond. The intensity of the correlations of the factors affecting the resultant as well as the correlations between the two showed values in Table 6.

Table 6

\section{Correlation coefficient values of selected factors (after modification) ${ }^{5}$}

\begin{tabular}{|ccccccc|}
\hline & $Y$ & $X_{2}$ & $X_{3}$ & $X_{4}$ & $X_{5}$ & $X_{7}$ \\
\hline$Y$ & 1 & & & & & \\
$X_{2}$ & 0,733068 & 1 & & & & \\
$X_{3}$ & 0,995639 & 0,71377 & 1 & & & \\
$X_{4}$ & 0,863642 & 0,65975 & 0,73971 & 1 & & \\
$X_{5}$ & $-0,354146$ & 0,08043 & $-0,39137$ & $-0,062260$ & 1 & \\
$X_{7}$ & 0,97662 & 0,60929 & 0,77473 & 0,761981 & $-0,382168$ & 1 \\
\hline
\end{tabular}

In addition to the 2 factors excluded from the model, we carry out a regression analysis based on the effect of exogen factors on the resultant factor on the basis of 5 factors of influence.

\footnotetext{
${ }^{4}$ Done by author.

${ }^{5}$ Done by author.
} 
In order to establish an econometric model that reflects the impact of the above-defined factor indicators on the number of employed population, used a non-linear link. In this case, the values of the factor indicators were logarithmic and regression analysis performed because of the smallest squares method using the correlation Eviews software package based on these values (Tab. 7). In the form of a non-linear connection using the Eviews program, the coefficients of the multifactor regression equation, as well as the indicators that represent the significance of the regression equation and coefficients, indicate that this connection is within the limits based on the specified criteria.

In assessing the importance and quality of a multi-factor econometric model determined on the basis of regression analysis, the main emphasis will be on the correlation density $\left(r_{y x}\right.$ - multiple correlation coefficient), determination coefficient $\left(R^{2}\right)$, Fisher criterion $\left(F_{\text {stat }}\right)$ and Student criterion ( $\left.t_{\text {stat }}\right)$ of the factors. In the economy of the Republic of Uzbekistan, the factors affecting the number of items indicate the density of contact with the endogen factor, or the multiple coefficient of correlation by selected exogen factors, high contact density $\left(r_{y x}=0,9981\right)$. The value of the determination coefficient is also higher, depending on the multiple coefficient of correlation $\left(R^{2}=0,9974\right)$. The value of the Fisher criterion for the defined regression equation is equal to $F_{\text {stat }}=1483,52$, the degree of its significance is high.

The importance of the Student criterion value in terms of regression coefficients is also higher than the table indicator value, that is, the significance of the criterion values is at the level of demand, and this indicates that the quality of the identified model is within the established limits. The Darbin-Watson criterion, which indicates the presence of autocorrelation or multicolleniarity in the regression equation, is equal to $D W=2,1$, which proves that the regression equation is within the optimal limit by the criterion. Identified reliability level of the models is also high in correlating with the time factor of exogen factors affecting the number of employed population in the economy.

Table 7

\section{Determination of the coefficients of the regression equation and the results of the examination}

\section{of the equation based on the criteries ${ }^{6}$}

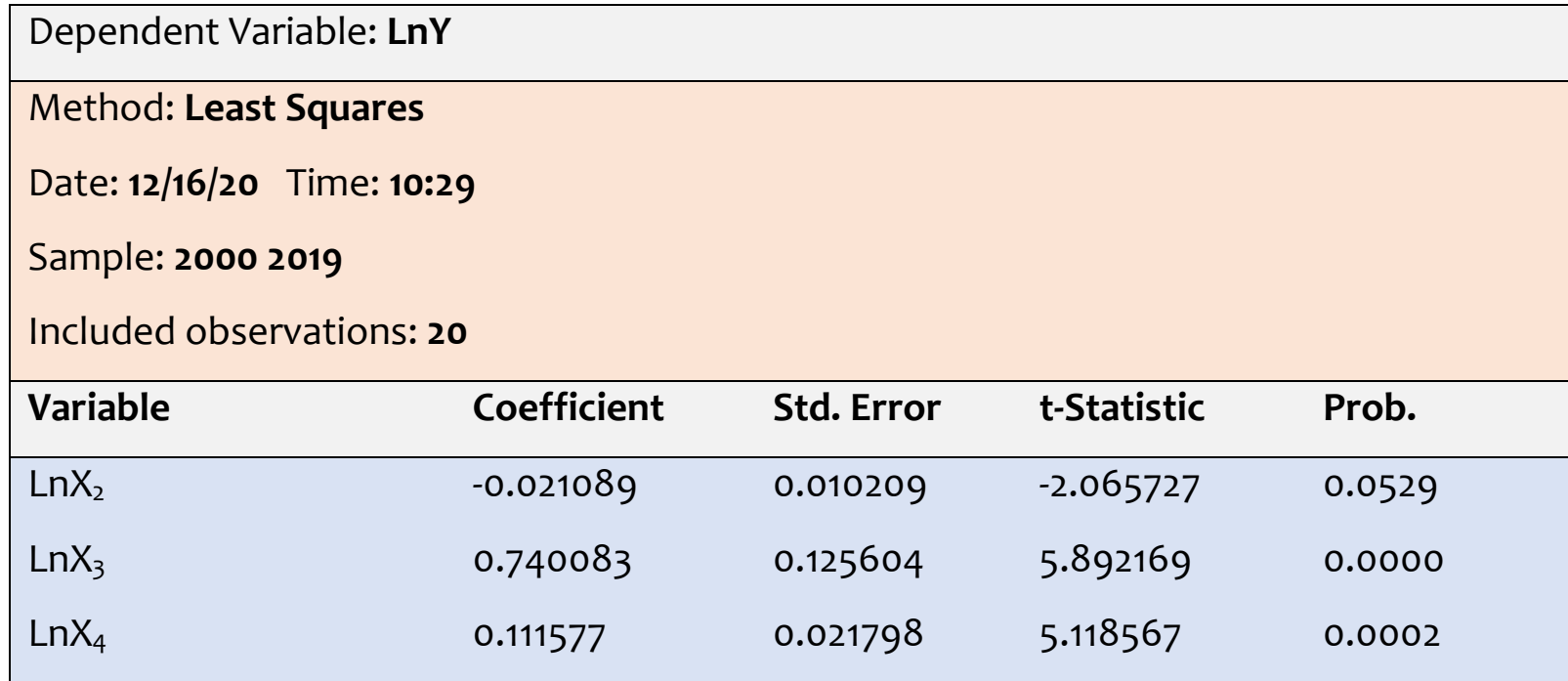

${ }^{6}$ Done by author. 
The American Journal of Management and Economics Innovations

(ISSN - 2693-0811)

Published: December 31, 2020 | Pages: 27-47

Doi: https://doi.org/10.37547/tajmei/Volume02Issue12-06

\begin{tabular}{|lllll|}
$\mathrm{LnX}_{5}$ & 0.015738 & 0.036872 & 0.426811 & 0.0076 \\
$\mathrm{LnX}$ & 0.153840 & 0.040958 & 3.756054 & 0.0021 \\
$\mathrm{C}$ & 1.045538 & 1.170340 & 0.893362 & 0.0868 \\
\hline R-squared & 0.998116 & Mean dependent var & 9.334441 \\
Adjusted R-squared & 0.997443 & S.D. dependent var & 0.140055 \\
S.E. of regression & 0.007082 & Akaike info criterion & -6.819295 \\
Sum squared resid & 0.000702 & Schwarz criterion & -6.520576 \\
Log likelihood & 74.19295 & Hannan-Quinn criter. & -6.760982 \\
F-statistic & 1483.520 & Durbin-Watson stat & 2.105541 \\
Prob(F-statistic) & 0.000000 & & \\
\hline
\end{tabular}

The importance of the parameters Investment volume per capita $\left(X_{2}\right)$ and the Consumer Price Index $\left(X_{5}\right)$ required to be checked by the main absolute percentage error $(\mathrm{MAPE}<10)$ and by the Theil Inequality Coefficient $(\mathrm{TIC}<1)$ at the statistical error of \pm 2 (Fig. 1).

Based on the value of the indicators shown in the picture, the significance of the regression equation parameters is determined by the Main Absolute Percentage Error (MAPE) and the Theil Inequality
Coefficient is much smaller than the specified limit, that is, MAPE - 0,05259<10 and TIC $0,000317<1$.

On the basis of a link in the form of a time series obtained as a high level of influence and strength on the level of employment of the population, we determine the multi-factor correlation and separate regression equations based on regression analysis by linking the number of employed population in the economy to the exfactors.

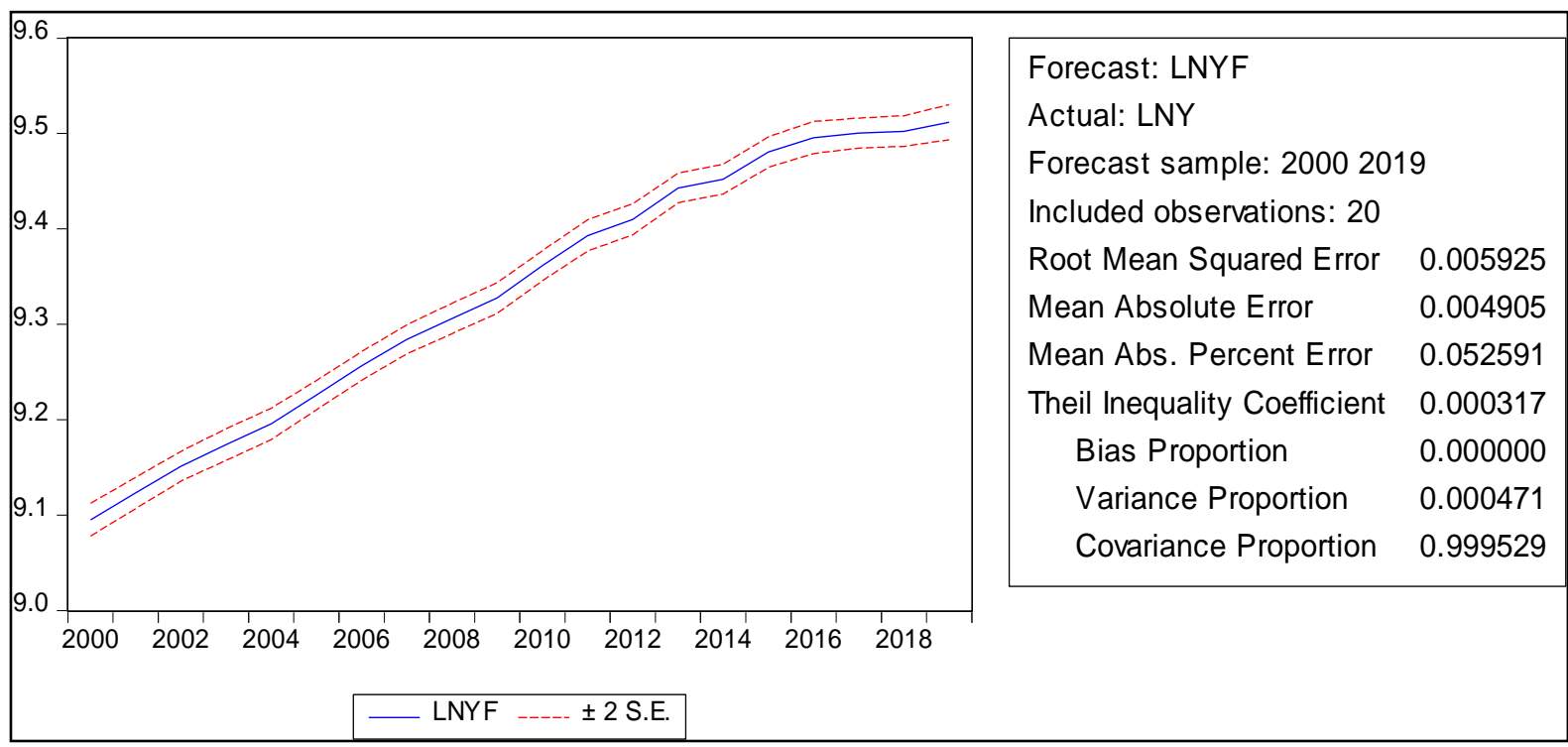


Figure 1. The results of the evaluation of the regression equation by the criteria MAPE and

$\mathrm{TIC}^{7}$

On the basis of the coefficients in Table 7, the multi-factor regression equation has the following form:

$$
\begin{gathered}
\operatorname{Ln} Y=-0,0211 \cdot x_{2}+0,74 \cdot x_{3}+ \\
0,112 \cdot x_{4}+0,016 \cdot x_{5}+0,154 \cdot x_{7}+1,046
\end{gathered}
$$$$
\text { (1.1) }
$$

The defined logarithmic regression equation is potentiated, and as a result, the regression equation will have the following form:

$$
Y=\frac{X 3^{0,74} * X 4^{0,112} * X 5^{0,016} * X 7^{0,154} * e^{1,046}}{X 2^{0,0211}}
$$

\section{(1.2)}

The economic essence of the generated (1.2) equation can be explained as follows. If the number of operating enterprises and the Number of population in working age is increased by one thousand, the number of employed population in the economy can be increased by 3,7 thousand and 0,5 thousand, respectively. If the Consumer Price Index and the share of small business and private entrepreneurship in the GDP increase by $1 \%$, the number of employed population in the economy will increase by 1,9 and 36,5 thousand people. But at present, it is determined that the increase in the investment volume of the main capital per capita by a thousand soums leads to a decrease the number of employed population in the economy to 50 people.

We identify models of changes in the influence of exogen factors of influence on the time factor:

$$
\begin{aligned}
& x_{2}=-483,4+315,9 \cdot t \\
& x_{3}=11413,6+372,2 \cdot t \\
& x_{4}=86,1+15,6 \cdot t \\
& x_{5}=111,2+0,2 \cdot t \\
& x_{7}=26,5+1,5 \cdot t
\end{aligned}
$$

On the basis of the identified models, we determine the forecast indicators of the duration of the medium term (for the 20202026 years) of the exogen and endogen factors (Tab. 8).

The forecasts indicates that, under normal economic conditions without a pandemic in the Republic of Uzbekistan during 2020-2026 years the number of employed population in the economy and the indicators of the factors affecting it will have a steady growth trend.

\footnotetext{
${ }^{7}$ Done by author.
} 


\section{Table8}

Forecasts of the number of employed population in the economy and the factors affecting it of the Republic of Uzbekistan in 2020-2026

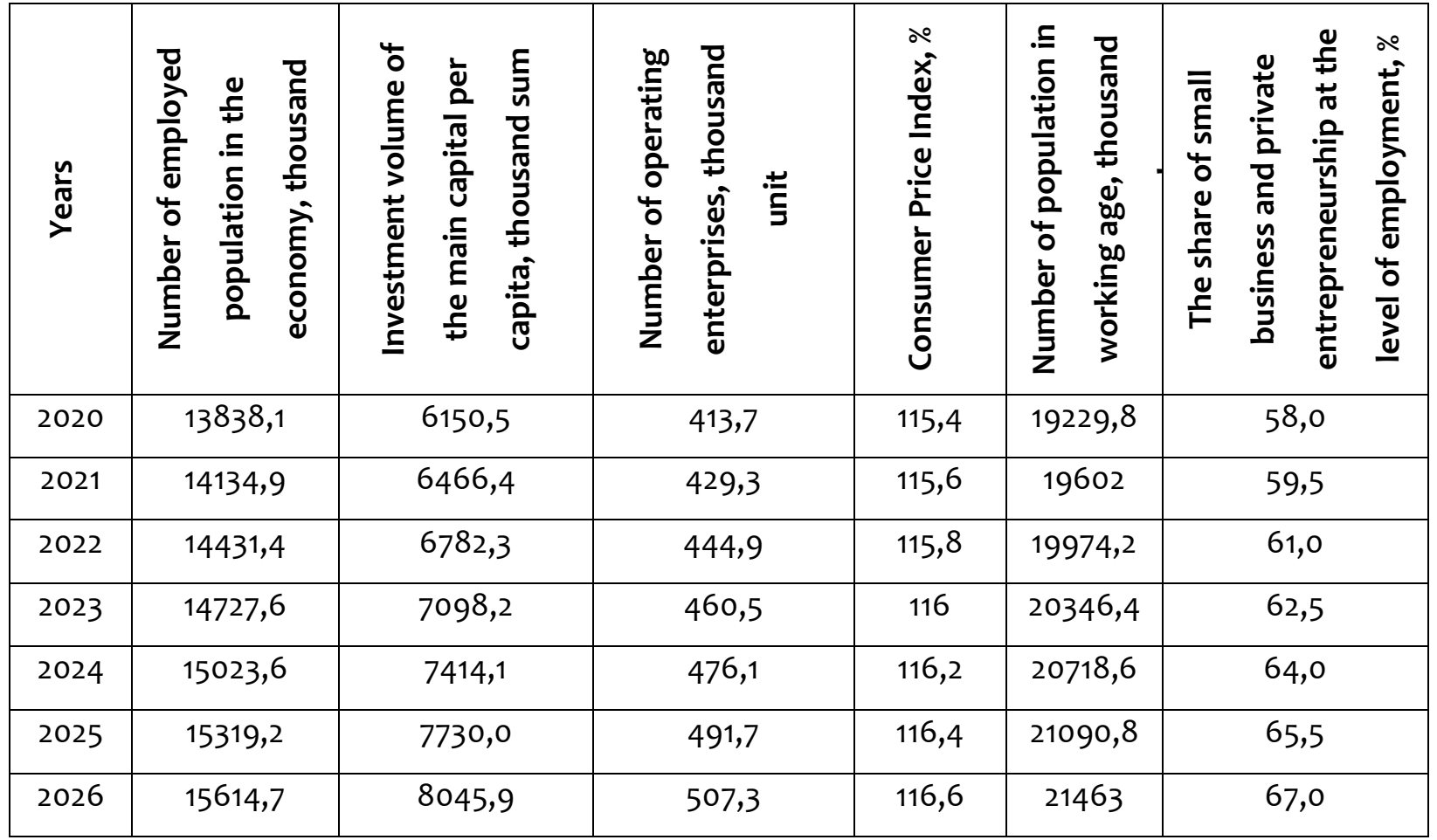

Of course, there is a possibility of a change in the real situation of the forecast indicators identified in the current period with the influence of changes in certain economic processes.
The forecast indicators, calculated for a medium period based on the identified econometric model, indicate that in the future the number of employed population in the economy will have a tendency to grow due to changes in the indicators of the factors affecting it (Fig. 2).

\footnotetext{
${ }^{8}$ Done by author.
} 


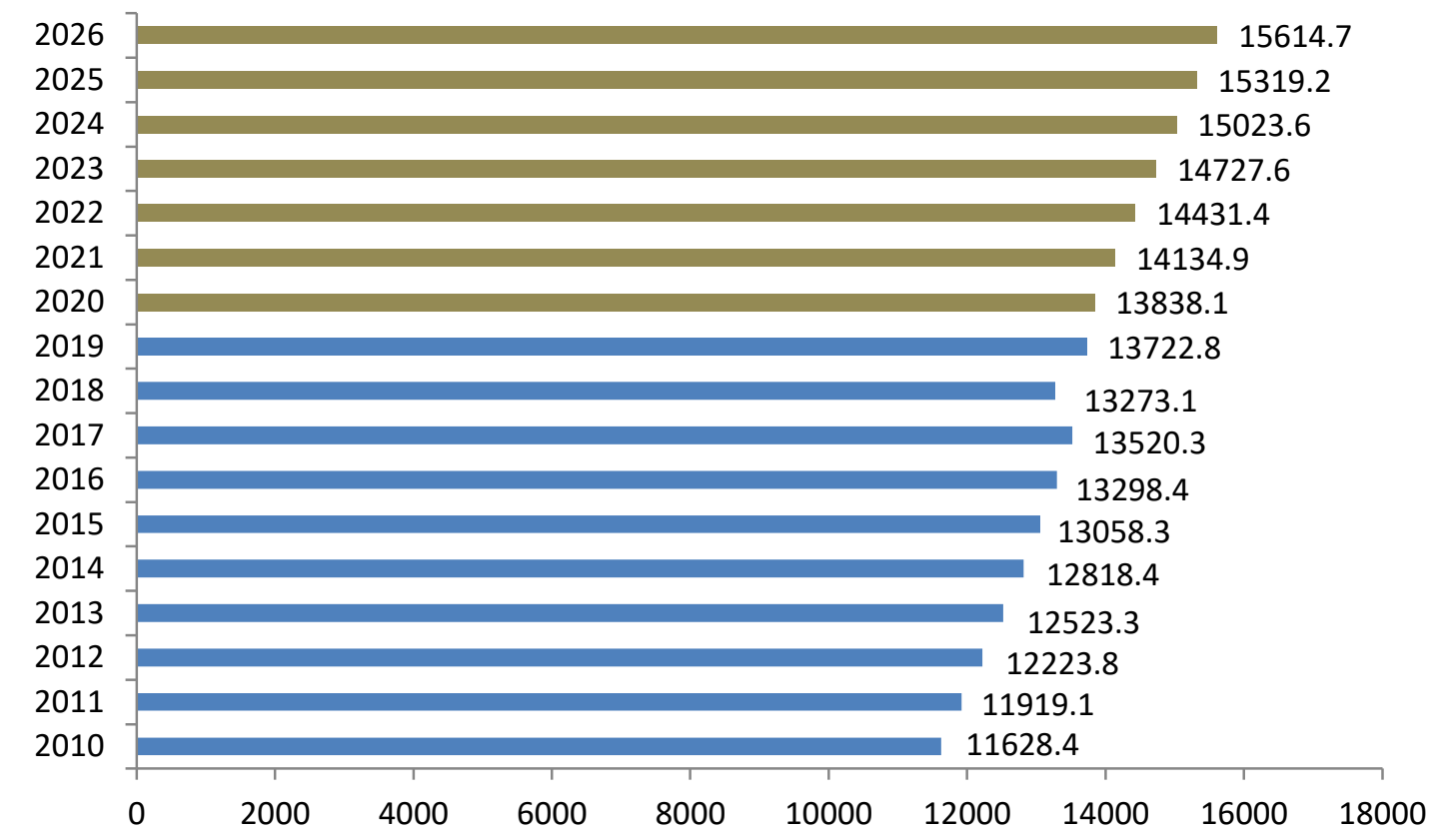

Figure 2. Indicators of change in the number of employed population in the economy of Uzbekistan, thousand people ${ }^{9}$

These changes are caused by the quality changes observed in the economic and sociodemographic indicators at the level of the country, which are considered in the analyzes we carried out above.

\section{CONCLUSIONS}

Proceeding from the analysis of the factors affecting the employment of the population carried out, we think that in order to increase the level of employment of labor resources in the labor market of the country by the relevant structures of national and Regional Public Administration, the following activities are required:

1. Increasing the number of new jobs by organizing the activities of new business entities and expanding the activities of existing entities on the account of increasing the volume of investments in sectors and spheres of the economy, as well as the main capital attracted on the basis of the territorial approach.

2. Depending on the natural growth of the population, it is planned that the amount that is added to the number of working-age population every year will be brought to the optimal level by changing the demographic policy directions that are carried out at the regional and country levels [28, 39-42].

3. To optimize the volume of production (service) of enterprises (organizations, institutions) operating in the sectors and sectors of the economy due to the current economic situation, increasing the number of enterprises with the optimal number of employed population to the account.

\footnotetext{
${ }^{9}$ Done by author.
} 
4. To bring the Consumer Price Index (inflation rate), which directly affects the level of effective employment of the population through increasing the effectiveness of antiinflation measures of the state (targeting, etc.) to a stable state and prevent its sharp increase [29, 46-50].

5. Legal regulation of migration processes, making the most optimal the level of migration balance by determining the agreement (quota)with foreign countries on the migration direction of labor resources based on the optimal limits of the migration surplus.

6. Increase the nominal salary rate of the population in proportion to the level of inflation and the size of the consumer basket.

7. Constantly increasing its share in employment with the sustainable formation of new jobs by further improving the conditions for the development of small business, private and family entrepreneurship [30, 698-704].

As a result of the activities in the mentioned directions, the effective employment situation in the country is ensured, and in the middle future by means of modeling, the level of welfare is steadily increased by increasing the employment level of the population.

\section{REFERENCES}

1. World Employment and Social Outlook: Trends 2019. International Labour Office Geneva: ILO, 2019. p. 5.

2. https://kun.uz/news/2020/04/03/aqshdabir-hafta-ichida-ishsizlar-soni-rekorddarajada-kopaydi.

3. Генкин М.Б. Экономика и социология труда: учебник. 2-изд-е. - М.: НОРМАИНФРА, 1999. С. 88-89. / Genkin B.M. Labour Economics and sociology: textbook. 2-nd publ. -M.: NORMA-INFRA, 1999. pp. 88-89.

4. Узякова Е.С., Узяков М.Н. Занятость и эффективная занятость в российской экономике // Проблемы прогнозирования. - 2011, № 6. - С. 89-101.
I Uzyakova E.S., Uzyakov M.N. Employment and effective employment in the Russian economy // Problems of Forecasting. - 2011, № 6. - pp. 89-101.

5. Асракулов, А. (2019). Неформальная занятость и анализ факторов, влияющих на неформальную занятость в Узбекистане. Региональная экономика: теория и практика. 2019. Т. 17. № 12 (471). C. 2328-2336. / Asrakulov, A. (2019). Informal employment and analysis of factors affecting informal employment in Uzbekistan. Regional economy: theory and practice. 2019. Vol. 17. No. 12 (471). pp. 2328-2336.

https://doi.org/10.24891/re.17.12.2328.

6. Аронова С.А. Качество рабочей силы и факторы его формирования. - Орел: Орловский государственный университет, 2004. С. 222. / Aronova S.A. Quality of labor force and factors of its formation. - Orel: Orel State University, 2004. p. 222.

7. Mirzaev, A.T (2018) "The level of use of tourist attractions in the regions and the factors affecting them," Economics and Innovative Technologies: Vol. 2018: No. 3, Article 19. Available at: https://uzjournals.edu.uz/iqtisodiyot/vol20 $18 /$ iss3/19

8. Зайцева, К.В. Управление трудовой занятостью в условиях смешанной экономики: монография / К.В.Зайцева. Донецк: МЧП «ВИК», 2003. С. 261. / Zaitseva, K.V. Management of labor employment in a mixed economy: monograph / K.V.Zaitseva. - Donetsk: MCHP "VIC", 2003. p. 261.

9. Никольская, Г.К. Влияние глобализации экономических связей на состояние рынка труда в США / Г.К.Никольская // Труд за рубежом. - 2000, № 1. - C. 13-16./ Nikolskaya, G.K. The Impact of Globalization of Economic Relations on the State of the Labor Market in the United States / G.K.Nikolskaya // Labor Abroad. 2000, No. 1. - pp. 13-16. 
10. Лукьянова К.К. Зарубежный опыт регулирования занятости населения. Вестник ЮУрГУ. Серия «Экономика и менеджмент». 2016, Т. 10, № 3. С. 109-115. / Lukyanova K.K. Foreign experience of employment regulation. - Bulletin of SUSU. Series "Economics and Management". 2016, Vol. 10, no. 3. pp. 109-115.

11. Туленков, М.В. Организационноуправленческие основы регулирования занятости в Германии / М.В.Туленков // Бюл. ИПК ГСЗУ. - 2004, № 1. С. 50-54. / Tulenkov, M.V. Organizational and managerial bases of employment regulation in Germany / M. V. Tulenkov / / Byul. IPK GSPU. - 2004, No. 1. pp. 50-54.

12. Асрақулов, А. (2020). Норасмий бандликка концептуал ёндашувлар ва унинг Ўзбекистон мехнат бозоридаги даражаси. Biznes Expert, №145 (1), 106110. I Asrakulov, A. (2020). Conceptual approaches to informal employment and its level in the labor market of Uzbekistan. Business Expert, №145 (1), 106-110.

13. Асрақулов, А. (2020). Ўзбекистонда ахоли бандлигидаги тенденцияларнинг эконометрик тадқиқи. Иқтисодиёт ва таълим, №5, 86-89. / Asrakulov, A. (2020). Econometric research of trends in employment of population in Uzbekistan. Economics and education, №5, 86-89.

14. Асрақулов, А. (2020). Пандемия шароитида ахоли бандлигига таъсир этувчи омилларнинг бандлик кўрсаткичларига таъсирини бошқариш жараёнларини моделлаштириш. Молия ва банк иши электрон илмий журнали, №2, 218-224. / Asrakulov, A. (2020). Modeling the processes of managing the impact of factors affecting employment performance on the population under pandemic conditions. Electronic scientific journal of Finance and banking, №2, 218224.

15. Асрақулов, А. (2019). Норасмий бандликка концептуал ёндашувлар ва унга таъсир этувчи омиллар тахлили. “Иқтисодиёт ва инновацион технологиялар" илмий электрон журнали, № 6, 55-68. / Asrakulov, A. (2019). Analysis of contextual approaches to informal employment and factors affecting it. Scientific electronic journal "Economics and innovation technologies", № 6, 55-68.

16. Мирзаев А. Т. Совершенствование системы электронного бронирования как часть цифрования управленческой деятельности туристско-рекреационных предприятий // Бюллетень науки и практики. 2020. Т.6. №8. С.165-172. / Mirzaev A. T. Improving the electronic booking system as part of the digitization of management activities of tourist and recreational enterprises // Bulletin of science and practice. 2020. Vol. 6. No. 8. pp. 165-172. https://doi.org/10.33619/24142948/57/14

17. Mirzaev A. T. Evaluation of innovation capacity resource components in effective management of recreational clusters on the basis of econometric analysis // EPRA International Journal of Research and Development (IJRD). - 2020. - pp. 131-137. https://doi.org/10.36713/epra4790

18. Мирзаев А. Т. Совершенствование интегральной оценки механизма рекреационно-туристических объектов // Бюллетень науки и практики. 2019. Т. 5. №2. С. 27-134. / Mirzaev, A. T., Improvement of the integral evaluation of the mechanism of recreation and tourism objects // Bulletin of science and practice. 2019. Vol. 5. No. 2. pp. 27-134. https://doi.org/10.33619/2414-2948/39/17.

19. Мирзаев А.Т. Оценка использования рекреационных возможностей на рынке туристических услуг // Региональная экономика: теория и практика. - 2019. T. 17, № 5. - C. 990 - 1002. / Mirzaev A. T. Evaluation of the use of recreational opportunities in the market of tourist services / / Regional economy: theory and practice. - 2019. - Vol. 17, No. 5. - p. 9901002. https://doi.org/10.24891/re. 17.5.990 
20. Ханкелдиева корпоративного Г.Ш. Особенности акционерных управления в обществах с государственным участием // Бюллетень науки и практики. Электрон. журн. 2017. №11 (24). C. 357-363. / Khankeldiyev G. S. Peculiarities of corporate management in joint-stock companies with state participation // The Bulletin of science and practice. Electron. Journal. 2017. no. 11 (24). pp. 357-363. Режим доступа: http://www.bulletennauki.com/honkeldiy eva

21. Ханкелдиева, Г. Ш. Жизненный цикл корпорации и формирование приоритетов в реализации экономических интересов ее субъектов. Наука сегодня: опыт, традиции, инновации [Текст]: материалы, 46. / Khankeldieva, G. Sh. The life cycle of a corporation and the formation of priorities in the implementation of the economic interests of its subjects. Science today: experience, traditions, innovations [Text]: materials, 46.

22. Ханкелдиева Г. Ш. Перспективы развития электроэнергетической отрасли Республики Узбекистан в условиях модернизации экономических отношений // Бюллетень науки и практики. Электрон. журн.2017. №12 (25). C. 293-299. / Khankeldiyev G. S. Prospects of development of electric power industry of the Republic of Uzbekistan in the conditions of modernization of economic relations // Bulletin of science and practice. Electron. Journal. 2017. No. 12 (25). pp. 293299. Режим доступа: http://www.bulletennauki.com/honkeldiy eva-g

23. Khankeldieva G.Sh. Theoretical and economic prerequisites for the development of regional industrial clusters in the economy of the republic of uzbekistan // EPRA International Journal of Research and Development (IJRD). - 2020. - pp. 234-240. https://doi.org/10.36713/epra 4855.
24. Ханкелдиева Г. Ш. Электроэнергетика тармоғини узоқ муддатга мўлжалланган стратегияси // Иқтисодиёт ва инновацион технологиялар. Электрон. журн. 2018. №5. / Khankeldieva G. Sh. Long - term strategy of electroenergetic Network / / Economy and innovation technologies. Electronic. Corn. 2018. №5.

25. Орипов, А. А. Сфера услуг как экономическая категория и эффективный вид экономической деятельности. Наука сегодня: опыт, традиции, инновации [Текст]: материалы, 43. / Oripov, A. A. Service sector as an economic category and an effective type of economic activity. Science today: experience, Traditions, innovations [Text]: materials, 43.

26. Орипов, А. А. (2019). Развитие информационно-коммуникационных технологий в Узбекистане. Образование и наука в России и за рубежом, (16), 192194. / Oripov, A. A. (2019). Development of information and communication technologies in Uzbekistan. Education and Science in Russia and Abroad, (16), 192-194.

27. Орипов, А. А. Приоритетные направления развития сферы услуг Республики Узбекистан. Финансовоправовые $и$ инновационные аспекты инвестирования экономики региона. Сборник материалов международной научно-практической конференции. 2020. C. 334-339. / Oripov, A. A. Priority directions of development of the service sector of the Republic of Uzbekistan. Financial, legal and innovative aspects of investing in the region's economy. Collection of materials of the international scientific and practical conference. 2020. S. 334-339.

28. Mirzarahimov, B. H. (2020). The Tasks Of Tourism In Aesthetic Education: The Harmony Of Historicity And Modernity. The American Journal of Social Science and Education Innovations,2(09), 652-658. 
29. Mirzarahimov, B. (2019). The factor of good neighborhood and tourism development (Philosophical analysis). Scientific Bulletin of Namangan State University, 1(1), 140-145.

30. Asrakulov, A. S. (2017). Some aspects of development of the labor market of the Republic of Uzbekistan. In “Актуальные проблемы социально-гуманитарных наук" (рр. 39-42).

31. Асрақулов, А. (2019). Бандлик моделларини тадқиқ этишга концептуал ёндашувлар. Biznes Expert, №142(10), 4650.34. / Asrakulov, A. (2019). Contextual approaches to the study of employment models. Business Expert, №142 (10), 46-50.

32. Асрақулов, А.С. (2020). Некоторые аспекты методологии определения неформальной занятости в Узбекистане и определения её границ. “Финансовоправовые и инновационные аспекты инвестирования экономики региона" (С. 698-704) / Asrakulov, A. S. (2020). Some aspects of the methodology for determining informal employment in Uzbekistan and defining its borders. "Financial, legal and innovative aspects of investing in the region's economy" (pp. 698-704). 